\title{
Tempers flare over plan to move Pasteur labs
}

Declan Butler, Paris

Scientists at the Pasteur Institute in central Paris are protesting over plans to relocate part of the prestigious research centre to a commercial zone on the outskirts of the city. So bitter has the row with management become that the institute has called in an outside mediator to defuse the tension.

Over the past few months, hundreds of Pasteur scientists have received letters from management informing them that their labs will be moving to Fresnes for several years while the central campus is renovated. Some of the institute's most senior scientists are among those told they will move. Staff object not only to the move itself but also to how the decisions have been made.

Researchers say that the 17,000-squaremetre Fresnes site in the Val-de-Marne region southeast of Paris is in an undesirable commercial zone with poor public transport. And with little hope of attracting good young scientists, they argue, the move would be a recipe for intellectual death by isolation.

Almost half of the staff have already signed a petition stating that they "understand neither the necessity, nor the rationale" of the move, which they claim "would be a major scientific handicap" to the institute.

The Fresnes site, estimated to be worth some $€ 13$ million (US\$17 million), was donated to the Pasteur earlier this year by the drug firm Pfizer. The institute says the site solves space problems for the renovation and will allow for a planned expansion. Local authorities have promised to provide subsidies of $€ 4.3$ million for the Pasteur as the core of a planned biotech science park, according to the Val-de-Marne Economic Development Agency.

Agnès Labigne, head of the Pasteur's

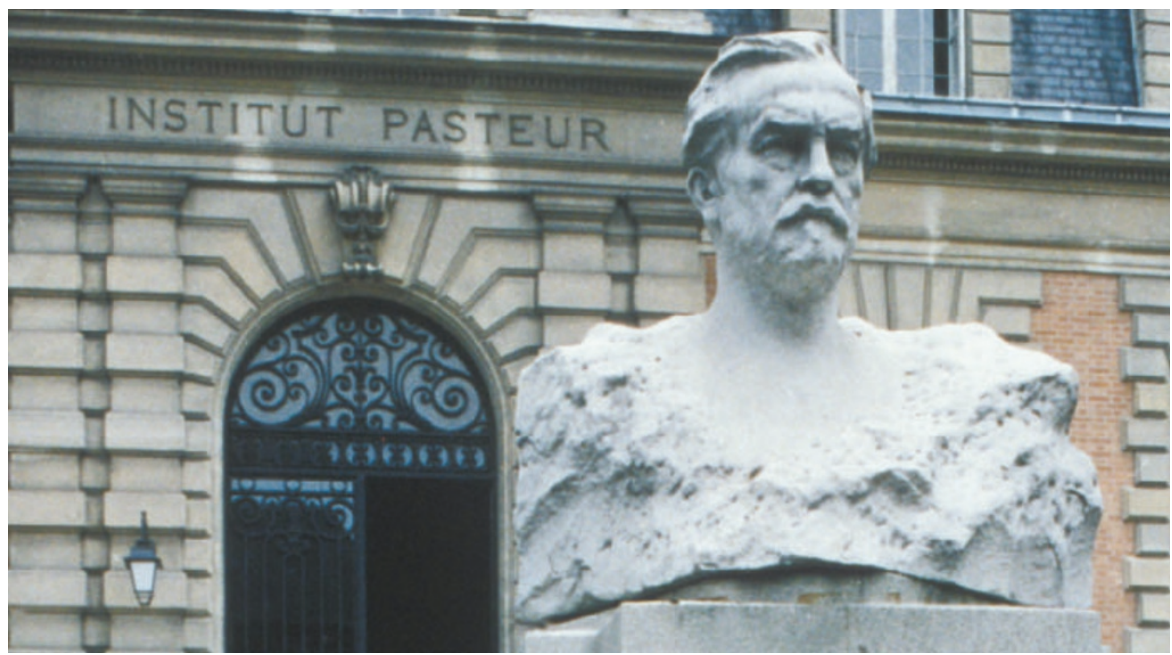

Researchers at the Pasteur Institute claim a move to the outskirts of Paris will compromise their work.

Pathogenesis of Mucosal Bacteria unit, says the renovations are being used as a "pretext" to justify "Fresnes at any price". She stepped down as head of her department in March because, she says, the Pasteur management ignored the conclusions of a task force that the renovation could be carried out without displacing groups to Fresnes.

The relocation row has also brought to a head tensions over what staff see as the brash management style of the institute's directorgeneral, Philippe Kourilsky. He wrote in a letter to the scientists that the early notices about the move were "badly received by many of you, who judged it brutal, and were rightly astonished that it was not preceded or accompanied by personal contact with management". He says management had intended to talk to them on the day the notes were sent.

Kourilsky was travelling and unavailable for comment. But senior vice-president for scientific affairs Stewart Cole, acting spokesman in Kourilsky's absence, admits that there is a problem. "At the moment there are a lot of difficult decisions to be made, or to be reversed. I don't think the consultation has been good," says Cole. But he adds: "Everyone genuinely feels they are acting in the best interests of the Pasteur."

Cole and Philippe Sansonetti, head of the institute's cell-biology department, have now persuaded management to bring in a mediator, John Skehel. Skehel is director of Britain's National Institute for Medical Research in London - itself no stranger to fights over site relocation (see Nature 432, 662;2004).

"The situation has got completely out of hand," says Cole. "We need a few months to see what the most sensible way out is. But we need to do this in a concerted, open and constructive manner." Skehel is expected to deliver his initial conclusions by the end of January.

\section{Relaxed rules open path to genomic data on disease}

\section{David Cyranoski, Washington}

To the delight of researchers mining the human genome for disease-related genes, restrictions on the use of data from the International HapMap Project were dropped last week. The information can now be incorporated into other databases, allowing easy access for scientists around the globe.

Researchers seeking the genetic component of a specific disease are interested in single nucleotide polymorphisms (SNPs) - points in the genome where one base often differs between individuals. But there are an estimated ten million common SNPs, so it is quicker to search for common haplotypes linked to a disease - larger blocks of DNA that are often inherited together. The
HapMap project is a consortium of some 25 groups, which have been collecting data on haplotypes since October 2002.

When the US\$100-million project began, organizers were worried that people would mine the data and attempt to patent haplotypes. So users had to agree not to limit access to the information, for example by patenting it, and not to share the data with anyone who hadn't made the same agreement.

But this had the unfortunate side effect that data could not be integrated into large, open-access genomic databases such as Ensembl. "We could pick up the data and do a lot of analysis, but we couldn't give it back to anyone," says bioinformatician Ewan Birney, who heads Ensembl.
Those restrictions have now been lifted. Birney predicts that the increase in Ensembl data will throw up haplotypes for diseases such as Alzheimer's, diabetes or heart disease within the next two years. "It will switch on the light," he says. "For some diseases, major risk factors will be discovered."

HapMap partners hope that haplotypes related to specific diseases will be commercialized, says Lisa Brooks, a director of the US Genetic Variation Program, but that basic haplotype information will remain freely available. Brooks adds that enough data and analysis are now public that claims of novelty needed to secure a patent should be difficult to prove. www.hapmap.org 